\title{
ESTIMASI KEPADATAN ULAT API MELALUI METODE SAMPLING JARAK
}

\author{
Cukri Rahmi Niani ${ }^{1}$ \\ ${ }^{1)}$ Jurusan Teknik Sipil, Fakultas Teknik, Universitas Teuku Umar \\ Email: cukrirahmi@utu.ac.id
}

\begin{abstract}
Many types of pests which is found in oil palm plantations such as rats, bees and the caterpillars. Caterpillar and the bagworm, including a caterpillar eaters leaves oil palm plantations. This Research focuses on a caterpillar type Setora nitens at oil palm plantations Karya Tanah Subur in West Aceh. Many ways that has been done to overcome pests caterpillar in oil palm plantations from early monitoring and extermination caterpillar. To know the density caterpillar can be done by counting directly individual caterpillar or with other methods that in this research, the density caterpillar in the estimation through distance sampling techniques. Distance sampling is one of the methods used to estimate the density and the spread population. The sampling distance, a series point or lines are placed randomly on the districts census and measured the distance between individuals who were detected in handcuffs or this point. Ordered Distance, Point Quarter and Variable Area Transect the distance sampling method that used in the research. Based on the explanation, an extensive microinsurance is focused on the estimation density caterpillar using the distance sampling methods.
\end{abstract}

Keywords: Setora nitens, Distance Sampling, Order Distance, Point Quarter, Variable Area Transect.

\section{PENDAHULUAN}

Berbagai macam hama ditemukan di kelapa sawit. Mulai dari hama pemakan pohon, pemakan buah hingga hama pemakan daun kelapa sawit. Di Indonesia, seperti daerah Sumatera kelapa sawit diserang oleh hama tikus dan di daerah Kalimantan kelapa sawit terserang hama ulat. Namun di beberapa daerah lain ada beberapa hama jenis serangga yang menyerang [1].

Pada beberapa tahun terakhir ini, banyak perkebunan kelapa sawit di Indonesia terserang hama ulat pemakan daun. Ada beberapa jenis hama ulat pemakan daun seperti ulat kantong dan ulat api. Dari kedua jenis ulat tersebut, ulat api menjadi hama yang sangat merugikan kelapa sawit. Terdapat banyak spesies ulat api yang menyerang kelapa sawit di Indonesia. Untuk daerah tertentu, ulat api ini sudah menjadi endemik atau menetap sehingga sangat sulit dikendalikan. Meskipun tidak mematikan tanaman, hama ini sangat merugikan secara ekonomi [2]. Oleh karena itu, untuk para petani dan peneliti memerlukan suatu cara untuk mengantisipasi hama tersebut.

Banyak upaya yang telah dilakukan untuk mengendalikan berbagai macam hama khususnya ulat api. Salah satunya yaitu pengendalian secara alami dan secara kimiawi. Sebelum melakukan tindakan pengendalian, seorang peneliti perlu mengetahui kepadatan hama pada suatu lokasi. Informasi kepadatan hama dibutuhkan sebagai acuan melakukan tindakan pengendalian dan penanganan selanjutnya. Oleh karena itu, dibutuhkan suatu alat atau metode yang bisa memperkirakan kepadatan suatu populasi secara akurat. 
Metode atau alat tersebut diharapkan dapat mengukur kepadatan awal suatu populasi hama dengan tepat.

Salah satu metode yang sering digunakan yaitu metode sensus. Dengan metode sensus, suatu kepadatan hama dapat diketahui yaitu dengan menghitung semua hama secara keseluruhan pada suatu lokasi. Jika populasi hama kecil, maka kepadatan dapat dihitung dengan metode sensus. Namun, jika metode sensus digunakan pada populasi yang besar tentu akan membutuhkan waktu yang lama dan biaya yang tidak sedikit. Sehingga beberapa peneliti mengembangkan metode yang lebih cepat dan hemat biaya. Salah satunya yaitu metode sampling jarak.

Sampling jarak adalah suatu cara atau metode yang digunakan untuk memperkirakan kepadatan atau penyebaran populasi [3]. Metode sampling jarak adalah metode yang dirancang lebih hemat biaya dan lebih cepat dibandingkan dengan metode sensus. Pada sampling jarak, titik dan garis digunakan sebagai dasar pengukuran, dan hanya beberapa individu yang dihitung. Beberapa ahli ekologi telah mengembangkan metode sampling jarak menjadi beberapa metode. Setiap metode diklasifikasi berdasarkan titik atau garis yang digunakan. Sehingga setiap metode bisa disesuaikan dengan jenis dan sifat dari objek yang akan diteliti.

Metode sampling jarak telah banyak digunakan untuk mengestimasi kepadatan populasi hewan. Seperti yang dilakukan menggunakan sampling jarak untuk mengestimasi kepadatan burung camar di wilayah Thailand [4]. Penerapan teknik sampling [5] jarak untuk mengestimasi kepadatan satwa liar di pulau Santa Cruz. Selanjutnya [6] menggunakan sampling jarak untuk mengetahui kepadatan burung Grenada Dove (Leptotila wellsi) yang hampir punah di pulau Grenada.

\section{METODOLOGI PENELITIAN}

Metode penelitian meliputi dua kegiatan. Pertama melakukan survei lokasi ataupun tempat. Selanjutnya melakukan pengukuran data jarak ulat api pada tanaman kelapa sawit. Survei lokasi yang dilakukan untuk memperoleh informasi tentang tingkat serangan hama. Penelitian dilakukan pada perkebunan kelapa sawit PT.Karya Tanah Subur (KTS). Perkebunan tersebut berlokasi di Desa Padang Sikabu, Kecamatan Kaway XVI, Kabupaten Aceh Barat.

Pada tiap lokasi sampel, data diukur berdasarkan ketiga metode sampling jarak, yaitu metode Jarak Terurut, Titik Kuadran dan VAT. Sehingga diperoleh data berupa jarak antara ulat api. Kemudian kepadatan ulat api juga dihitung berdasarkan metode tersebut. Selanjutnya data tersebut dianalisis berdasarkan uji statistik apakah mengikuti sebaran normal atau tidak. Jika data berdistribusi normal, maka dilakukan analisis variansi untuk mengetahui adanya perbedaan pada masing-masing metode.

\subsection{Ulat Api}

Ulat api merupakan salah satu hama serangga pada kelapa sawit. Simanjuntak dkk (2011) telah menuliskan beberapa macam ulat yang banyak menyebabkan kerusakan di Indonesia seperti Setothasea asigna, Setora nitens dan Darna catenatus. Khususnya pada perkebunan kelapa sawit Karya Tanah Subur (KTS) ulat api yang menyerang yaitu Setora nitens dan ulat kantong (Bagworm). Pada penelitian ini, jenis ulat api yang dijadikan objek penelitian adalah S.nitens. 


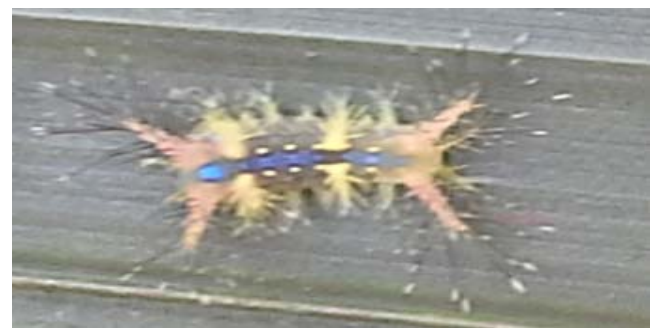

Gambar 1. Larva S.nitens. (Sumber: foto penelitian)

S.nitens merupakan salah satu jenis ulat api pemakan daun kelapa sawit yang paling sering menimbulkan kerugian di perkebunan kelapa sawit. Umur serangga ini sekitar 50 hari. Larva serangga ini dicirikan dengan adanya satu garis membujur di tengah punggung yang berwarna biru keunguan. Selama perkembangannya, S.nitens berganti kulit 7-8 kali dan mampu menghabiskan helaian daun seluas $400 \mathrm{~cm} 2$. Siklus hidup serangga ini bisa terlihat pada Gambar 2 dibawah ini

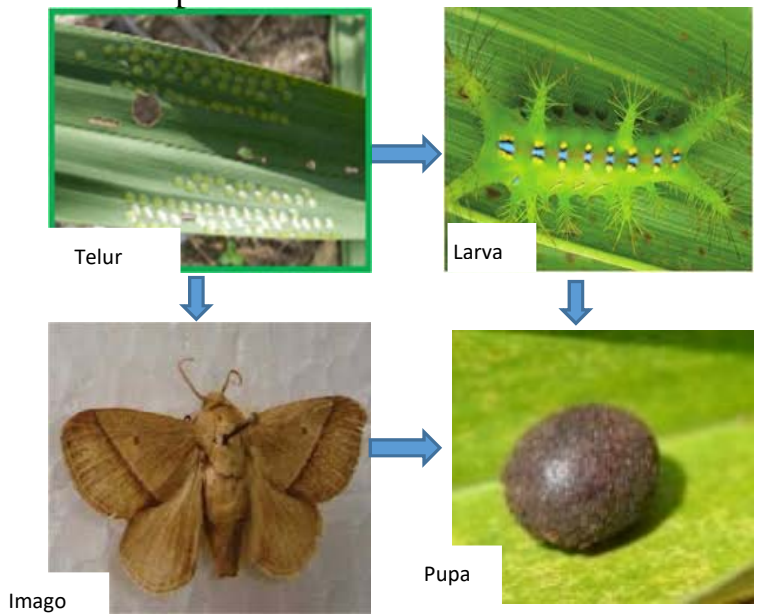

Gambar 2. Siklus nıdup Setora nitens bermula dari telur berkembang menjadi larva, larva berubah menjadi pupa dan akhirnya menjadi imago. (www.google.com, 2015)

Telur S.nitens berbentuk pipih dan berwarna bening, lebarnya $3 \mathrm{~mm}$, diletakkan pada permukaan bawah daun dalam 3-5 deretan, kadangkala mencapai 20 deret dan peletakan telur antara satu sama lain tidak saling tindih (lihat Gambar 2). Telur menetas menjadi larva setelah 4-7 hari.

Larva serangga ini mula-mula berwarna hijau kekuningan kemudian hijau dan biasanya berubah menjadi kemerahan menjelang masa pupa. Panjang larva mencapai 40 $\mathrm{mm}$, mempunyai dua rumpun bulu kasar di kepala dan di bagian ekor. Larva ini dicirikan dengan adanya satu garis membujur di tengah punggung yang berwarna biru keunguan (lihat Gambar 2).

Selanjutnya larva berubah menjadi pupa. Serangga ini berpupa pada permukaan tanah di bawah pangkal batang kelapa sawit. Masa pupa berlangsung selama 17-27 hari, pupa berwarna coklat kemerah-merahan (lihat Gambar 2).

Fase terakhir pupa berubah menjadi Imago. Imago serangga ini berupa ngengat. Ngengat jantan dengan lebar rentang sayap sekitar $35 \mathrm{~mm}$ dan betina sedikit lebih lebar dari ngengat jantan. Ngengat berwarna cokelat kelabu dengan garis hitam pada tepi sayap depan, dengan panjang $20 \mathrm{~mm}$ pada betina dan lebih pendek pada jantan (lihat Gambar 2). Ngengat aktif pada senja dan malam hari, sedangkan pada siang hari hinggap di 
pelepah-pelepah tua atau pada tumpukan daun yang telah dibuang dengan posisi terbalik[7].

Populasi S.nitens pada awal kehadirannya diketahui berupa kelompok-kelompok kecil, kemudian akan berkembang semakin membesar pada generasi berikutnya, dan akhirnya kelompok-kelompok hama tersebut akan saling menyatu dan memenuhi hamparan tanaman kelapa sawit yang luas.

Serangan S.nitens di lapangan umumnya mengakibatkan daun kelapa sawit habis dengan sangat cepat dan berbentuk seperti melidi. Tanaman tidak dapat menghasilkan tandan selama 2-3 tahun jika serangan yang terjadi sangat berat. Umumnya gejala serangan dimulai dari daun bagian bawah hingga akhirnya helaian daun berlubang habis dan bagian yang tersisa hanya tulang daun saja. Serangga ini sangat rakus, mampu mengkonsumsi 300-500 $\mathrm{m} 2$ daun sawit per hari. Tingkat populasi 5-10 Serangga per pelepah merupakan populasi kritis dan harus segera diambil tindakan pengendalian.

\subsection{Sampling Jarak}

Terdapat suatu metode yang digunakan untuk memperkirakan kepadatan atau penyebaran populasi yaitu metode sampling jarak. Pada teori sampling jarak, suatu himpunan garis atau titik secara acak ditempatkan atau didirikan dan jarak diukur untuk objek-objek yang terdeteksi pada garis atau titik pusatnya[3]. Sampling jarak memungkinkan untuk beberapa atau lebih objek terdeteksi. Selain itu, objek yang terdeteksi cenderung menurun sesuai dengan peningkatan jarak dari garis atau titik transek. Sampling jarak telah berhasil digunakan untuk mengestimasi kepadatan populasi biologi yang sangat beragam, misal pada serangga, amfibi, reptil, burung, ikan dan pohon-pohon.

Ada tiga unsur yang harus diketahui di dalam sampling jarak yaitu lajur (Strip), garis transek (Line transect) dan titik transek (Point transect). Ketiga hal tersebut sering digunakan bukan dalam satu metode, misalnya jika metode yang menggunakan garis transek harus menggunakan lajur sebagai batasan area sampel. Berikut akan dijelaskan secara khusus untuk masing-masing unsur tersebut. Pertama adalah Lajur merupakan batasan plot yang biasanya digunakan untuk membatasi area sampel (lihat Gambar 3). Panjang lajur adalah $L$ dan lebarnya $W$ (lebar area yang disensus). Semua benda yang ada di lajur akan terdeteksi, namun sebaliknya untuk objek yang ada di luar lajur diabaikan. Dalam hal ini, diperlukan survei lajur dalam pengambilan sampel untuk menentukan letak garis dan titik. Dalam hal inilah letak perbedaan antara metode sampling jarak dengan metode sensus biasa. Dalam metode sensus semua objek dalam area dihitung dan disurvei, tetapi dalam metode sampling jarak hanya beberapa bagian objek yang dihitung dan dicatat.

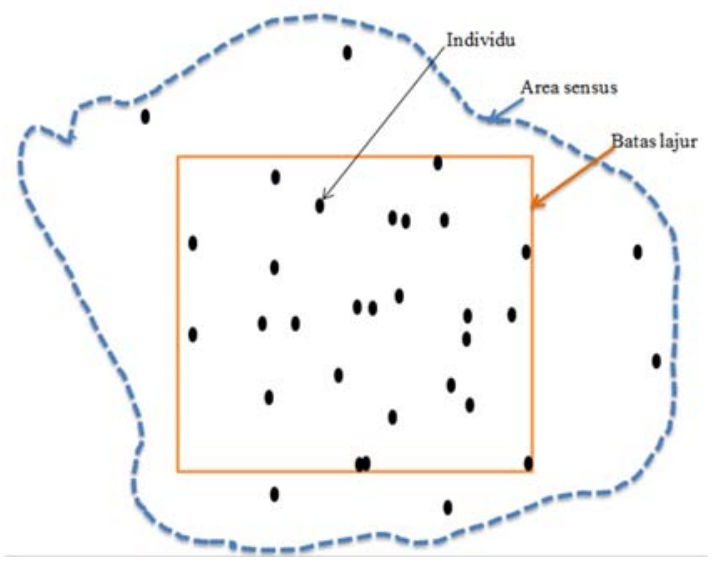


Gambar 3. Ilustrtasi lajur yang dibatasi oleh area sensus. Dalam beberapa kasus ada beberapa individu yang berada diluar batas lajur.

Kedua adalah Garis transek, garis transeck adalah bentuk khusus dari lajur, pada lajur keseluruhan objek di dalamnya diasumsikan terdeteksi, namun pada garis transek diasumsikan tidak semua objek terdeteksi. Letak garis transek diasumsikan dapat mewakili lajur yang disurvei, misalkan salah satu garis transek diletakkan di tengah lajur (lihat Gambar 4). Garis transek yang lurus dilalui oleh pengamat dan jarak tegak lurus dari setiap objek yang terdeteksi diukur terhadap garis. Garis transek diletakkan secara acak pada lajur dan diketahui panjangnya L. Dalam prakteknya digunakan sejumlah garis $11,12, \ldots, 1 \mathrm{k}$, maka jumlah dari panjang garis ditulis sebagai L. Objek akan terdeteksi sejauh garis transek, jika jaraknya dicatat dengan akurat maka estimasi kepadatannya dapat dihitung.

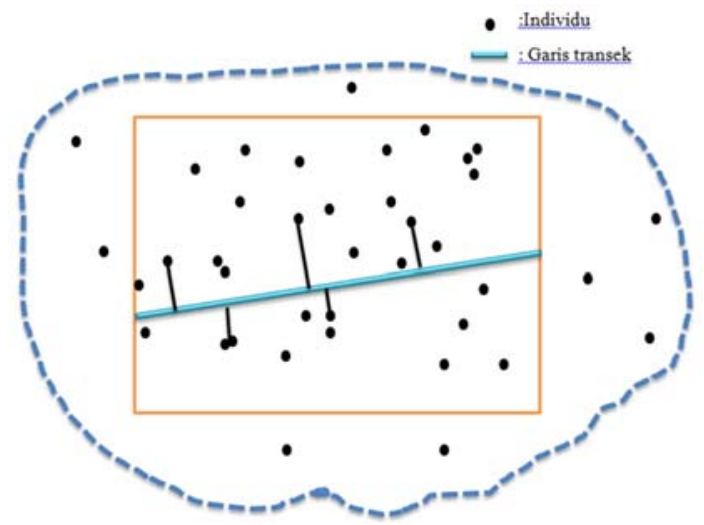

Gambar 4. Ilustrasi garis transek dengan satu garis sepanjang L. Lima individu $(n=5)$ yang terdeteksi pada jarak x1, x2....x5.

Ketiga adalah titik transek, istilah titik transek bisa dipandang sebagai garis transek yang panjangnya nol. Analogi ini dibatasi hanya sebagai perbedaan konsep antara garis dan titik. Titik transek sering juga disebut plot lingkaran, dimana titik sering diletakkan sepanjang interval garis lurus. Sejumlah $\mathrm{k}$ titik diletakkan pada posisi secara acak. Peneliti akan mengukur jarak ri dari titik acak ke tiap objek yang terdeteksi (lihat Gambar 5). Pada area sampling berbentuk lingkaran, maka luas area yang disensus adalah $\pi w^{2}$ Buckland dalam [8].

Jika area pada sampel lajur dan garis transek adalah $w L$, sedangkan area yang dicari pada bentuk lingkaran dan titik transek adalah $k \pi r^{2}$, dimana $k$ dan $\mathrm{r}$ masingmasing adalah banyaknya titik acak dan panjang dari titik ke individu. Pada lajur diasumsikan area yang disensus semua objek terdeteksi. Pada garis dan titik transek hanya sebagian kecil dari objek yang dideteksi untuk keseluruhan area, kemungkinan hanya $10-30 \%$ area. 


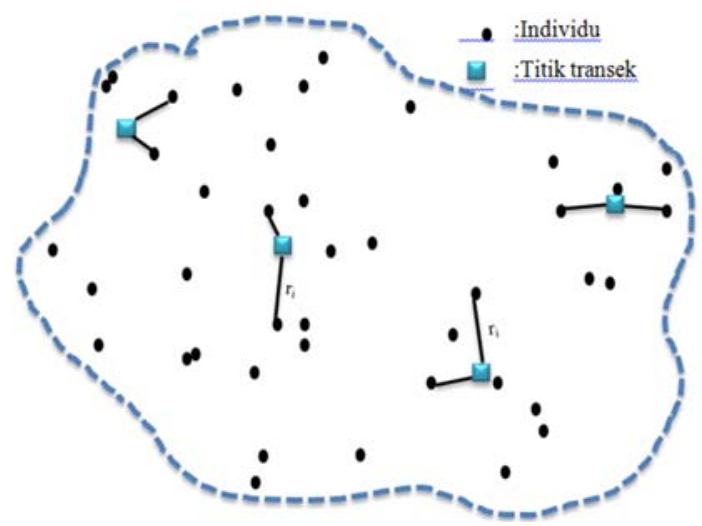

Gambar 5. Ilustrasi titik transek dengan 4 titik acak $(\mathrm{k}=4)$. Delapan individu $(\mathrm{n}=8)$ yang terdeteksi pada jarak ${ }^{r_{1}, r_{2}, \ldots, r_{8}}$.

\subsection{Metode Sampling Jarak}

Terdapat beberapa metode sampling jarak. Metode tersebut digunakan untuk mengestimasi kepadatan melalui garis atau titik transek. Pada tiap-tiap metode tersebut, memiliki dua pendekatan umum. Pertama individu dipilih secara acak dan diukur jarak dengan tetangga terdekat. Kedua titik acak dipilih dan diukur jarak dari titik ke organisme terdekat. Berikut dijelaskan masing-masing metode serta teknik yang digunakan.

\subsection{Metode Jarak terurut}

Metode jarak terurut pertama kali di usulkan oleh Morisita pada tahun 1957 dan dikembangkan lebih lanjut oleh Pollard pada tahun 1971. Metode [3] ini melibatkan pengukuran jarak titik random dengan individu terdekat. Pollard adalah orang pertama yang mengakui bahwa variansi estimasi suatu populasi meningkat sesuai dengan jarak individu, sehingga untuk mengestimasi kepadatan suatu populasi lebih tepat dengan melibatkan pengukuran jarak antara individu terdekat kedua dengan individu terdekat. Dalam praktiknya metode ini lebih cocok untuk pola mengelompok. Metode ini dikembangkan untuk meningkatkan pengawasan ketika supervisor memiliki waktu terbatas dan membutuhkan biaya yang besar. Metode ini juga bisa digunakan untuk mengestimasi individu terdekat dan terdekat kedua.

Bentuk umum estimasi populasi dengan metode jarak terurut ditunjukkan oleh persamaan berikut:

$$
\widehat{D}=\frac{N g-1}{\pi \sum R_{(g) i}^{2}}
$$

Dengan $N$ adalah banyak titik acak dan g merupakan individu terdekat yang digunakan, misalkan si peneliti menghitung jarak dari titik acak ke individu terdekat pertama maka $g=1$. Selanjutnya $R_{(g) i}^{2}$ adalah kuadrat jarak dari titik acak ke individu terdekat (lihat Gambar 6). 


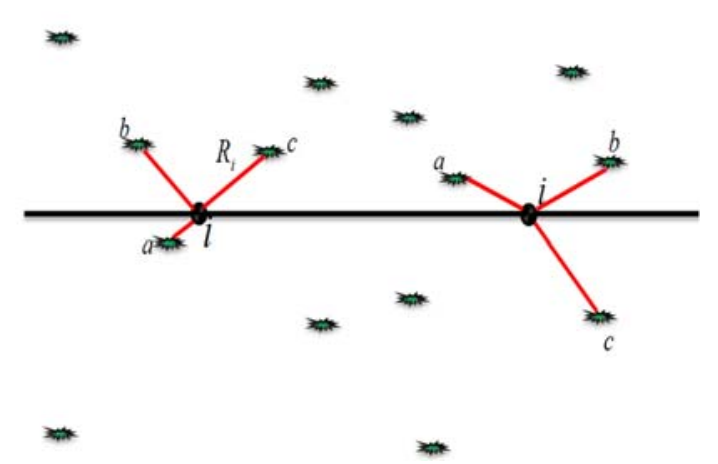

Gambar 6. Ilustrasi estimasi kepadatan dengan metode jarak terurut. Jarak diukur dari titik acak (i) ke individu terdekat pertama (a), ke individu terdekat kedua (b) dan ke individu terdekat ketiga (c). Masing-masing titik acak diukur jarak ke tiap individu sepanjang Ri.

\subsection{Metode Titik kuadran}

Metode titik kuadran adalah metode klasik yang dikembangkan pertama kali oleh supervisor tanah di Amerika Serikat pada abad kesembilan belas. Metode ini pertama kali digunakan pada bidang ekologi oleh Cottam dan Curtis pada tahun 1956. Krebs [3] menjelaskan bahwa metode titik kuadran yaitu dengan meletakkan serangkaian titik-titik acak pada sepanjang garis transek dengan syarat titik acak tidak boleh terlalu dekat dengan individu. Daerah di sekitar titik acak dibagi menjadi empat kuadran $90^{\circ}$ dan jarak ke individu terdekat diukur dalam masing kuadran (lihat Gambar 7). Metode ini dikembangkan untuk populasi yang berkembang biak karena penularan.

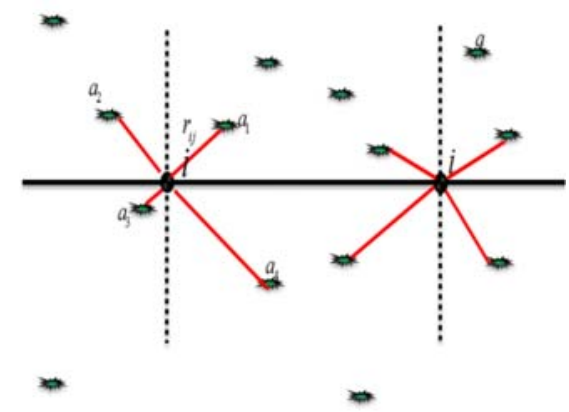

Gambar 7. Ilustarsi estimasi populasi dengan metode titik kuadran. Masing-masing titik acak (i) diletakkan di sepanjang garis transek, tiap titik acak dibagi menjadi empat kuadran. Jarak (rij) diukur dari titik i acak ke individu terdekat pada tiap kuadran $\mathrm{j}$.

Formula umum estimasi populasi dengan metode titik kuadran diberikan:

$$
\widehat{N}_{p}=\frac{N k(g k-1)}{\pi \sum\left(r_{(g) i j}^{2}\right)}
$$

Dimana $N$ merupakan banyak titik acak, sedang $\mathrm{k}$ dan $\mathrm{g}$ masing-masing merupakan banyak sektor dan individu terdekat yang digunakan. Selanjutnya $r_{(g) i j}^{2}$ adalah kuadrat jarak titik acak i ke individu terdekat g pada kuadran $\mathrm{j}(\mathrm{j}=1,2, . ., \mathrm{k} ; \mathrm{i}=1,2, \ldots \mathrm{n})$. Berikut langkah kerja seperti untuk metode titik kuadran; 
Cari titik acak di zona studi.

Bagikan tiap titik acak menjadi empat kuadran $(j=1,2,3,4)$

Pada tiap-tiap kuadran tentukan individu terdekat pertama, terdekat kedua dan terdekat ketiga dari titik acak. Gunakan alat ukur yang akurat untuk jarak antar individu. Ukur jarak dari titik acak ke individu terdekat ketiga (R(3)ij), kedua (R(2)ij) dan individu terdekat pertama $(\mathrm{R}(1) \mathrm{ij})$.

Ulangi prosedur 1-4 hingga mencapai titik acak 20 hingga $50(20 \leq n \leq 50)$.

\subsection{Metode Variabel Area Transek (VAT)}

Metode ini merupakan kombinasi garis transek dan titik transek yang pertama kali di usulkan oleh Parker pada tahun 1979. Sebuah garis acak diletakkan pada lajur dan titik acak diletakkan di sepanjang garis[3]. Individu dicari hanya pada satu arah, panjang garis transek diukur dari titik acak dimana individu terdeteksi. Metode ini dapat digunakan untuk individu terdekat ke-n (lihat Gambar II.8). Metode ini dikembangkan ketika populasi bepola acak berbaris.

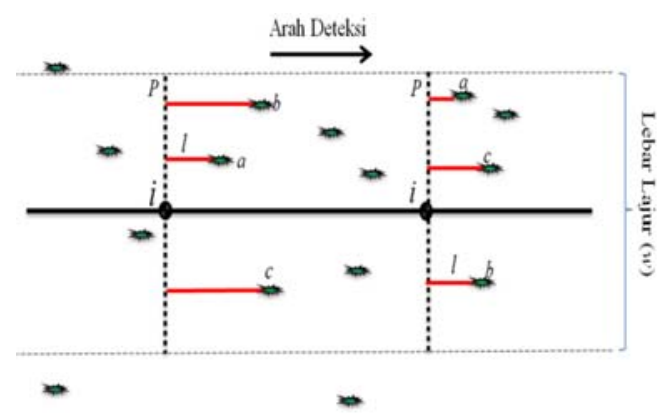

Gambar 8. Ilustrasi estimasi populasi dengan metode variabel area transek. Serangkaian titik acak diletakkan di sepanjang garis transek. Tiap individu terdekat pertama (a), kedua (b) dan ketiga (c) diukur jarak masing-masing ke proyeksi titik acak $(\mathrm{P})$ sepanjang 1 .

Formula umum untuk estimasi populasi dengan menggunakan metode VAT ditetapkan oleh Parker yaitu;

$\widehat{D}_{v}=\frac{N g-1}{w \sum\left(l_{(g) i}\right)}$

Dimana $N$ dan $g$ masing-masing adalah banyak titik acak dan individu yang

digunakan. Selanjutnya $w$ merupakan lebar lajur yang digunakan dan $l_{(g) i}$ adalah panjang garis transek ke-i ke individu terdekat $g$. Langkah kerja untuk sampling metode VAT seperti yang diberikan pada algoritma VAT berikut:

Tentukan titik acak pada garis transek di area studi.

Pindahkan titik acak sepanjang garis transek sampai ditemukan individu terdekat ke- $g$. Ukur jarak individu terhadap proyeksi titik acak pada garis transek ditandai dengan pita pengukur.

Ukur jarak dari titik acak ke titik proyeksi.

Ulangi langkah 1-4 hingga individu mencapai $30(30 \leq n \leq 50)$ 


\section{HASIL DAN PEMBAHASAN}

Data diperoleh melalui observasi langsung di lapangan terhadap serangan ulat api jenis S.nitens. Dengan melakukan pengamatan langsung di titik lokasi yang sudah di tentukan. Penelitian dilaksanakan pada perkebunan kelapa sawit PT.Karya Tanah Subur, Desa Padang Sikabu Kecamatan Kaway XVI, Kabupaten Aceh Barat. Penelitian dilakukan selama tiga hari, yaitu pada tanggal 1-3 Juni 2015.

Dalam satu hektar dengan ketentuan yang ada, dipilih 5 pohon kelapa sawit yang dijadikan sebagai data sampel. Banyak titik sampel yang diambil yaitu sebanyak 45 titik sampel. Ilustrasi banyaknya titik sampel dapat dilihat pada Gambar 9.

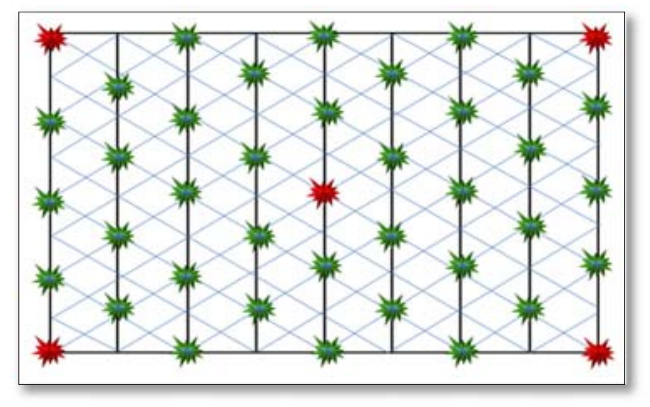

Gambar 9. Ilustrasi penentuan titik sampel pada lokasi pengamatan. Titik merah merupakan pohon yang dijadikan sebagai sampel.

Objek yang dijadikan sampel dalam penelitian adalah individu S.nitens dan tanda gigitan pada helaian daun kelapa sawit. Dalam penelitian jarak yang diukur adalah individu S.nitens dan tanda gigitan. Sehingga dalam pengumpulan data, jarak antara individu dan bekas gigitan dianggap dua hal yang sama. Pengamatan populasi S.nitens pada tanaman kelapa sawit dilakukan secara kasat mata. Tingkat kepadatan populasi dinyatakan berdasarkan jumlah larva S.nitens dan tanda gigitan yang ditemukan.

Pada setiap pohon diambil satu pelepah daun. Pengambilan pelepah dilakukan pada tanaman dengan kriteria pelepah daun yang masih baru mengalami serangan. Pada setiap pohon yang dipilih, hanya satu pelepah yang dipotong dengan tingkat serangan pada daun berdasarkan algoritma masing-masing metode.

Untuk memudahkan pengukuran jarak antara individu, peneliti menggunakan suatu alat sampling jarak yang terbuat dari kayu sepanjang 1 meter dan lebarnya 0,5 meter (lihat hambar 10). Alat ini dibuat untuk mengukur jarak S.nitens pada masingmasing metode, yaitu metode Jarak Terurut, Titik Kuadran dan VAT. Pada penulisan selanjutnya ketiga metode tersebut berturut-turut disebut metode $\mathrm{A}, \mathrm{B}$ dan $\mathrm{C}$.

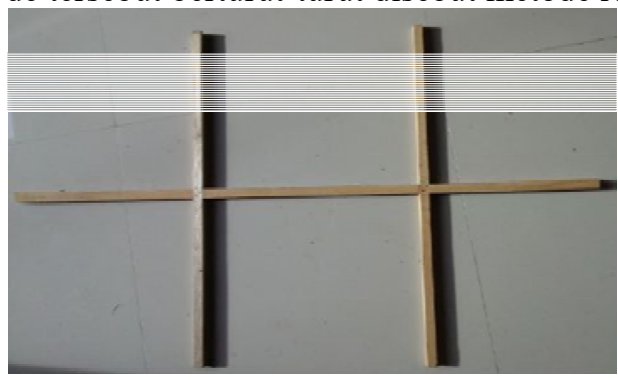

Gambar 10. Alat sampling jarak yang digunakan sebagai alat bantu mengukur jarak S.nitens pada pelepah kelapa sawit (foto penelitian, 2015) 
Alat sampling jarak tersebut diletakkan di tengah pelepah pada bagian ujung pelepah (lihat gambar 11), dan diukur jarak antara individu berdasarkan masing-masing metode.

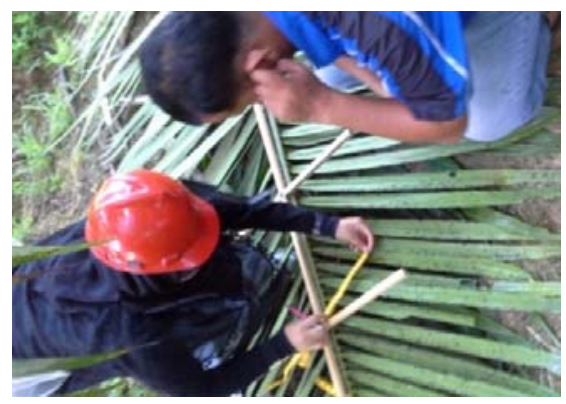

Gambar 11. Peneliti mengukur jarak antara titik acak dengan individu terdekat, yaitu dengan menggunakan alat sampling jarak yang diletakkan pada ujung pelepah daun (foto penelitian, 2015). Dengan menggunakan algoritma ketiga metode tersebut maka diperoleh data seperti pada grafik dibawah ini.

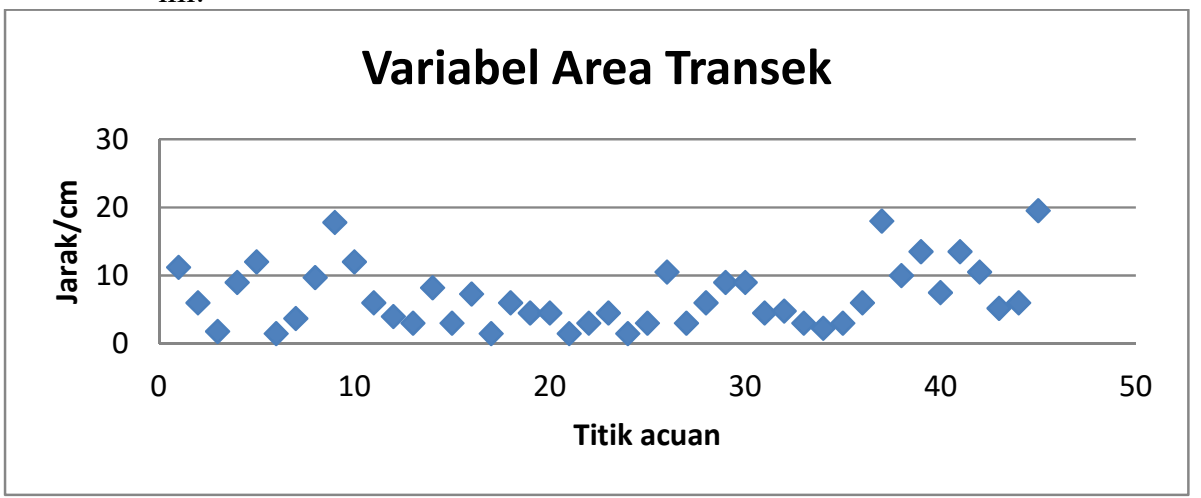

Gambar 12. Penyebaran individu ulat api berdasarkan metode Variabel Area Transek

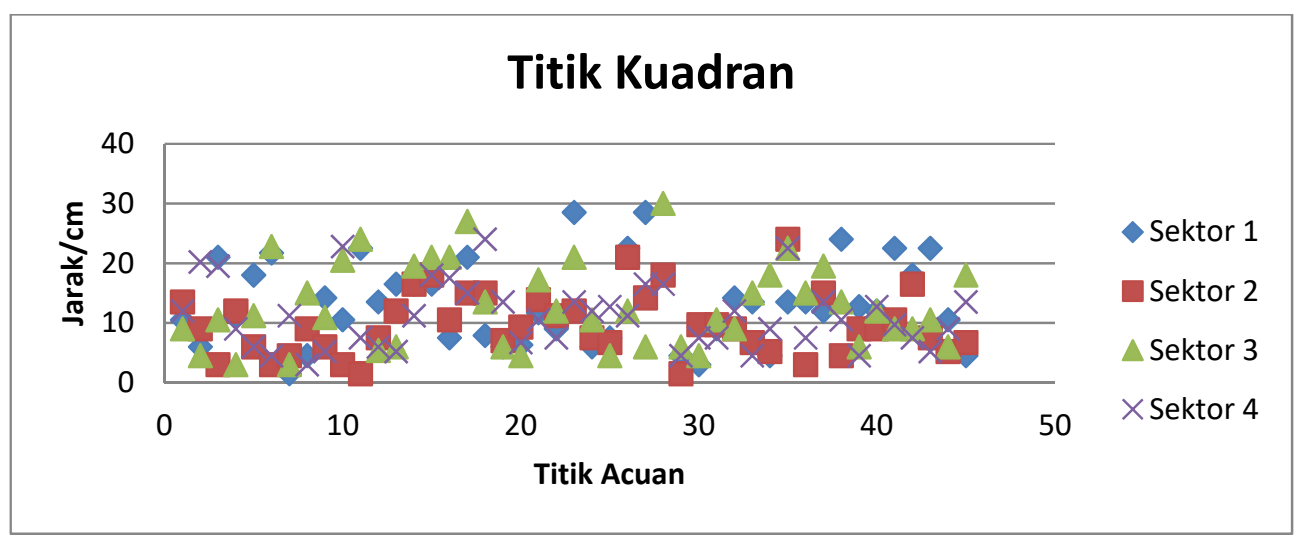

Gambar 13. Penyebaran individu ulat api berdasarkan metode Titik Transek, individu diukur dalam empat sektor 


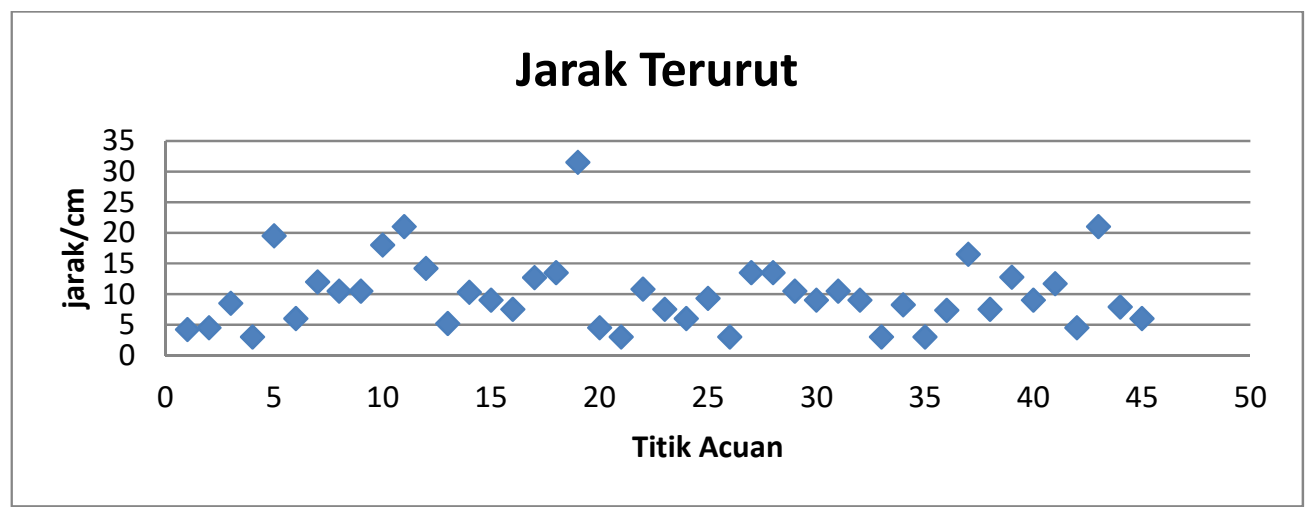

Gambar 13. Penyebaran individu ulat api berdasarkan metode Jarak Terurut

Data jarak yang diperoleh berdasarkan tiap-tiap metode ternyata berbeda-beda, baik dengan pendekatan individu yang sama ataupun individu yang berbeda. Hal ini yang menyebabkan harus dilakukan analisis statistik terdahulu pada tiap data. Oleh karena itu dilakukan pemeriksaan apakah terdapat nilai pencilan pada data, dan menguji sebaran data bersifat normal atau tidak.

Berdasarkan analisa yang telah dilakukan, ada beberapa data yang tidak mewakili populasinya. Hal ini disebabkan proses pengukuran yang berbeda-beda pada tiap metode. Tiap data mempunyai nilai sebaran yang bervariasi, hal tersebut membuat ada data yang tidak mengikuti sebaran normal. Dari ketiga metode yang digunakan, metode A dan $\mathrm{C}$ merupakan metode yang terpilih. Khususnya metode A dengan pendekatan individu b,c dan metode $\mathrm{C}$ dengan pendekatan individu c. Setelah dilakukan analisis variansi pada metode tersebut, dapat disimpulkan bahwa tidak ada perbedaan yang signifikan pada ketiganya. Artinya, walaupun data diperoleh dengan perlakuan yang berbeda, namun tidak membedakan data tersebut secara statistik.

Tabel 1. Nilai AD dan P-value untuk masing-masing data.

\begin{tabular}{|c|c|c|c|c|c|c|c|c|c|}
\hline & \multicolumn{3}{|c|}{ Pendekatan individu a } & \multicolumn{3}{|c|}{ Pendekatan individu b } & \multicolumn{3}{|c|}{ Pendekatan individu c } \\
\hline & A & B & $\mathrm{C}$ & A & B & $\mathrm{C}$ & A & B & $\mathrm{C}$ \\
\hline $\begin{array}{l}\text { Nilai } \\
\text { AD }\end{array}$ & 1,233 & 2,437 & 1,315 & 0,191 & 3,522 & 1,059 & 0,250 & 6,744 & 0,389 \\
\hline P-value & $<0,005$ & $<0,005$ & $<0,005$ & 0,892 & $<0,005$ & 0,008 & 0,727 & $<0,005$ & 0,371 \\
\hline
\end{tabular}

Dari analisa yang telah dilakukan, metode Jarak Terurut adalah metode yang paling sederhana dan mudah diterapkan dalam mengestimasi populasi. Data yang diperoleh melalui metode ini lebih mewakili penyebaran populasi ditandai dengan nilai AD yang lebih kecil dan nilai p-value yang lebih besar daripada metode lain. Oleh karena itu, metode Variabel Area Transek sangat baik jika digunakan untuk mengestimasi hama ulat api.

\section{KESIMPULAN}

Berdasarkan penelitian yang telah dilakukan, kepadatan ulat api bisa diestimasi melalui metode sampling jarak. Data yang diperoleh dengan menggunakan beberapa metode sampling jarak hampir sama. Dari ketiga metode yang telah diterapkan, metode 
Jarak Terurut dan Variabel Area Transek adalah metode terbaik dalam mengestimasi kepadatan ulat api.

\section{PUSTAKA}

[1] Kalidas, P. (2012). Pets Problems of Oil Palm and Management Strategies for Sustainability. ISSN:2168-9881.

[2] Sinaga, M., Oemry, S., dan Lisnawita. (2015). The Efectiveness of Several Techniques to Control Setothosea asigna on Vegetative Phase of Palm Oil in Greenhouse. Jurnal Online Agroekoteaknologi Vol.3, No.2:634-641.

[3] Krebs, C.J. (2013). Ecological Methodology. Harper Collins Publisher, Inc. New York

[4] Suwanrat, S., Ngoprasert, D., Sutherland, C., Suwanwaree, P., dan Savini, T. (2015). Estimating Density of Secretive Terrestrial Birds (Siamese Fireback) in Pristine and Degraded Forest Using Camera Traps and Distance Sampling. Global Ecology and Conservation 3(2015): 596-606.

[5] Sollmann, R., Gardner, B,. Richard, B.C., Andrew, R.J., dan Scott, T. (2015). An Open-Population Hierarchical Distance Sampling Model. Ecology 96(2), 325-331.

[6] Frank, F.R-M., Paulo, B., Fernando, S., dan Bonnie, L.R. (2015). Distance Sampling and Abundance Estimation of the Critically Endangered Grenada Dove (Leptotila wellsi). Cooper Ornithological Society 117, 2015, 87-93.

[7] Simanjuntak, D., Perdana, R.T.A., Priwiratama, H., Sodharto, Sipayung, A., Desmier, C.R., Prasetyo, A.E., dan Susanto, A. (2011). Setora nitens Walker. Informasi Organisme Pengganggu Tanaman Vol.H-0005.

[8] Thomas, L., Buckland, S.T., Rexstad, A.E., Laake, L.J, Strindberg, S,. Hedley, L.S., Bishop, B.R.J., Marques, A.T., dan Burnham, P.K. (2012). Distance software: Design and Analysis of Distance Sampling Surveys for Estimating Population Size. Jurnal of Applied Ecology 47, 5-14. 